\title{
RIVALITAS PADA PILKADA SERENTAK TAHUN 2015 DI KABUPATEN MAJENE
}

\author{
Rivalry in the 2015 Regional Haed Election \\ in Majene Regency \\ ASRIANI, ANDI NUR FIQHI UTAMI, \\ ZAINUDDIN LOSI
}

Email: asriani2001@gmail.com

Universtas sulawesi Barat

\begin{abstract}
The research aimed to determine and analyze the competition of candidate pairs and the effect of decisive elite on the candidate pairs in obtaining votes in the 2015 Regional Head Election in Majene Regency. The research was a qualitative study with descriptive analysis type conducted in Majene Regency. The informants were determined using purposive sampling method. The data were obtained through in-depth interview and library study. The data were analyzed using rivalry concept, capital strength approach, decisive elite concept, and exchange theory. The results of the research indicate that each candidate pairs competes with each other by maximizing the owned capital strength. Fahmi Massiara - Lukman victory is obtained because they are able to accumulate modalities, i.e. symbolic capital, financial capital and social capital. Rizal Sirajuddin - Mulyadi Bintaha pair is the second in obtaining votes by maximizing financial capital, and social capital. Arifin Nurdin - A. Irfan pair is the third as they do not maximizing financial capital, and the only have cultural capital. The involvement of elites in the 2015 Regional Head Election in Majene Regency has impact on candidate pairs in obtaining votes. The effects of decisive elites determine political position, title of nobility, and the owned financial ability. Decisive elites have interest in supporting the candidate pairs, i.e. to facilitate the vote in Majene in governor election of West Sulawesi.
\end{abstract}

Key words: competition, modality, decisive elite, Regional Head Election

\begin{abstract}
ABSTRAK
Penelitian ini bertujuan untuk mengetahui dan menganalisis persaingan pasangan calon serta pengaruh elit penentu terhadap pasangan calon dalam perolehan suara pada Pemilihan Kepala Daerah Serentak tahun 2015 di Kabupaten Majene. Penelitian ini dilaksanakan di Kabupaten Majene, menggunakan jenis penelitian kualitatif dengan tipe deskriptif analisis. Penentuan informan dilakukan secara purposive. Data diperoleh melalui wawancara mendalam dan kajian pustaka. Data dianalisis menggunakan konsep rivalitas, pendekatan kekuatan modal, konsep elit penentu dan teori pertukaran. Hasil penelitian menunjukan bahwa bahwa masingmasing pasangan calon melakukan persaingan dengan memaksimalkan kekuatan modal yang dimiliki. Kemenangan Fahmi Massiara-Lukman karena mampu mengakumulasi modalitas yaitu modal simbolik, modal finansial dan modal sosial. Pasangan Rizal Sirajuddin berada
\end{abstract}


diurutan kedua perolehan suara dengan memaksimalkan modal finansial dan modal sosial. Arifin Nurdin-A. Irfan berada diurutan ketiga karena tidak maksimalnya modal finansial hanya memiliki kekuatan pada modal kultural. Keterlibatan elit penentu pada PILKADA di Majene tahun 2015 memiliki dampak terhadap pasangan calon dalam perolehan suara. Pengaruh elit penentu terjabarkan pada jabatan politik, gelar bangsawan, dan kemampuan finansial yang dimiliki. Elit penentu memiliki kepentingan mendukung pasangan calon yaitu untuk memudahkan dalam perolehan suara di Majene pada PILGUB Sulawesi Barat.

Kata Kunci : Persaingan, Modalitas, Elit penentu, PILKADA

\section{PENDAHULUAN}

Tiga perubahan mendasar dalam mekanisme PEMILU setelah Presiden Soeharto jatuh dari tampuk kekuasaannya pada tanggal 21 Mei 1998. Perubahan pertama, kembalinya sistem multipartai dari sistem tri partai. Kedua, pada PEMILU 2004 diadakan dua kali, yaitu PEMILU memilih wakil-wakil rakyat dan memilih presiden secara langsung. Perubahan ketiga, terkait UU No.32 Tahun 2004 dipertegas melalui PP No.6 Tahun 2005 (tentang pemilihan, pengesahan pengangkatan dan pemberhentian Kepala Daerah dan Wakil Kepala Daerah) sebagai landasan dan pedoman pelaksanaan PILKADA (pemilihan kepala daerah) secara langsung.

Perubahan mekanisme PILKADA telah membuka ruang kesempatan kepada seluruh warna negara untuk dapat berpartisipasi dalam politik. Partisipasi politik tidak hanya dalam bentuk pemberian hak suara, melainkan adanya warga yang mendaftarkan diri sebagai kontestan di PILKADA.

Isu-isu rasial dalam perkembangannya menjadi sebuah cara yang dilakukan oleh politisi untuk bisa memenangkan persaingan. Proses menjatuhkan lawan dengan menggunakan politik ras sudah dilakukan sejak tahun 1940-an oleh Belanda sebagai bagian dari Devide et impera atau politik pecah belah yang mereka jalankan untuk melemahkan kekuatan bangsa Indonesia.

Potensi persaingan antara kandidat partai politik dan perseorangan yang bertarung dalam pemilihan kepala daerah serentak sangat ketat dibeberapa daerah, terutama di daerah khusus ibukota. Persaingan ketat berpotensi terjadi di kota besar karena banyak calon baik dari parpol maupun perseorangan yang mampu jadi lawan tanding setara.

Majene merupakan salah satu Kabupaten yang menggelar PILKADA serentak. Ada 3 (tiga) kontestan yang bersaing dalam pemilihan Bupati dan Wakil Bupati. Nomor urut satu (1) Pasangan Fahmi Massiara-Lukman, nomor urut (2) Arifin Nurdin-A. Irfan Sulaeman, nomor urut (3) Rizal Sirajuddin-Muliadi Bintaha. Ketiga kontestan sudah pernah bertarung pada tahun 2011 dan saling mengalahkan.

Pemilihan kepala daerah tahun 2011 persaingan terjadi antara pasangan Kalma Katta-Fahmi Massiara dan pasangan Arifin Nurdin-Rizal Muchtar. Hasil perolehan suara menempatkan pasangan Kalma Katta-Fahmi Massiara unggul 39,0 \%, posisi kedua pasangan Arifin Nurdin-Rizal Muchtar 25,1 \%, Ahmad Syukri Tammalele-Syaharia 19,5 \%, dan pasangan Rizal Sirajuddin-Rusbi Hamid dengan perolehan suara 16,4 \%. Dengan kemenangan pasangan Kalma Katta-Fahmi Massiara, maka Arifin Nurdin dan Rizal 
Sirajuddin menggugat pasangan pemenang di Mahkamah Konstitusi karena banyak kecurangan yang dilakukan oleh Kalma Katta-Fahmi Massiara. Namun gugatan itu ditolah oleh Mahkamah Konstitusi karena tidak memiiki bukti yang kuat.

Pemiihan kepala daerah tahun 2015 pasangan Fahmi Massiara-Lukman dan Arifin Nurdin-A. Irfan kembali bersaing. Dengan harapan jika melawan wakil Kalma Katta yaitu Fahmi Massiara pasangan Arifin Nurdin-A. Irfan akan memperoleh kemenangan. Persaingan yang terjadi karena polularitas masing-masing kandidat dengan modal politik yang dimiliki.

Momentum perebutan kursi Bupati yang ditinggal Kalma Katta dipengaruhi oleh kepentingan politik para calon Gubernur Sulawesi Barat yang pada waktu itu telah menyatakan kesiapannya bertarung di Pilkada Serentak tahun 2017. Pemilihan kepala daerah ini bisa menjadi rujukan bagi figur yang ingin bertarung pada pemilihan gubernur Sulawesi Barat tahun 2017. Figur tersebut adalah Ali Baal Masdar, Suhardi Duka berpasangan Kalma Katta, dan Muhyina Muin.

Salah satu faktor kemenangan Fahmi Massiara-Lukman karena mendapat dukungan dari Kalma Katta. Kalma Katta sebagai figur yang senior di Majene baik sebagai birokrat maupun politikus, menjadikannya diperhitungkan secara khusus dalam perpolitikan di Sulawesi Barat. Dalam kultur sosial Majene, Kalma Katta dianggap sebagai tokoh yang mampu menjadi 'tomawueng' bagi masyarakat Majene.

Rivalitas semakin menajam karena Ali Baal Masdar memantapkan dukungan ke pasangan Arifin Nurdin-A. Irfan. Langkah ABM mendukung calon Nomor urut 2 (dua) karena pasangan ini diusung partai Nasdem dan Gerindra yang juga mengusung ABM pada PILGUB 2017. Faktor lain, karena ABM dan A. Irfan masih memiliki hubungan keluarga. Pengaruh ABM di majene karena adanya hubungan kekerabatan dan istri ABM yaitu A. Ruskati merupakan anak dari mara'dia Banggae di Mandar Majene. Popularitas ABM tidak serta merta memuluskan langkah Arifin Nurdin-A. Irfan bersaing dengan rivalnya memenangkan PILKADA di Majene. Pasangan yang didukung ABM gagal meraih suara terbanyak di Majene dan berada diurutan terakhir perolehan suara. Berdasarkan Latar belakang masalah tersebut maka penulis tertarik untuk meneliti tentang "Rivalitas Pada Pilkada Serentak Tahun 2015 di Kabupaten Majene”.

Dari uraian diatas maka perumusan masalahnya adalah : (1) bagaimana persaingan antara pasangan calon dalam PILKADA serentak tahun 2015 di Kabupaten Majene ; (2) Bagaimana pengaruh elit penentu terhadap pasangan calon dalam perolehan suara pada PILKADA serentak di Kabupaten Majene tahun 2015.

\section{KERANGKA TEORI}

Konsep dari rivalitas menandakan suatu hubungan yang sangat kompetitif antara dua pelaku atau lebih.(Paul.R. Hensel, 1999:3) Bentuk rivalitas juga dapat terjadi pada suasana yang damai dan pada hubungan yang kurang kompetitif yang melibatkan dua pihak atau lebih kelompok. Sehubungan dengan PEMILU defenisi pesaing yaitu setiap kandidat atau kelompok (partai, kelompok pemilih, dsb) yang mencoba mendapatkan bagian dalam dasar pemilih.(Peter Schroder, 2003:68)

Teori Modal

Modal merupakan aset yang dimiliki individu dalam lingkungan sosialnya yang digunakan untuk menentukan posisi dalam suatu ranah. Beragam jenis modal dapat ditukar dengan 
modal-modal lainnya yang artinya modal bersifat dapat ditukar. Menurut Bourdieu terdapat empat jenis modal yaitu modal ekonomi, modal sosial, modal kultural dan modal simbolik.(George Ritzer, 2011:908) Modal ekonomi adalah semua sumber daya ekonomi individu atau segala bentuk kekayaan materi yang dimiliki oleh agen termasuk pendapatan, warisan, investasi atau tabungan yang berwujud uang, giro, emas dan perhiasan, saham, tanah, rumah serta barang mewah lain. Bisa juga berupa alat-alat produksi dan materi. Bourdieu sendiri menggolongkan modal budaya menjadi tiga dimensi yaitu, pertama incorporees yang meliputi pengetahuan umum, keterampilan, nilai budaya, agama, norma, dan bakat turunan. Kedua, objectives yang meliputi kepemilikan benda-benda budaya yang bernilai tinggi. Ketiga, institutionalise meliputi gelar, tingkat pendidikan, keahlian tertentu yang diperoleh melalui jenjang pendidikan. Modal sosial mengukur semua sumber daya yang berkaitan dengan kepemilikan jaringan sosial berkelanjutan dari semua relasi dan semua orang yang dikenal. Modal simbolik adalah jenis sumber daya yang dioptimalkan dalam meraih kekuasaan simbolik.

Elit Penentu

Keller mempersepsikan seorang elit penentu ditentukan oleh faktor umum yaitu klas sosial dan karir yang berspesialisasi.(Suzanne Keller, 1963:296)

1. Klas sosial meninggalkan sedikit keraguan bahwa berbagai anggota elit itu, khasnya ditarik dari klas-klas menengah masyarakat, adalah merupakan keturunan dari orangorang bisnis atau professional, yang dapat berusaha mendorong anak-anak mereka paling kurang memperoleh suatu pendidikan perguruan tinggi.

2. Jalur-jalur karir yang berspesialisasi (memiliki kemampuan tertentu). Didalam masing-masing elit, tenaga ahli terkait bidang tertentu sedang dalam keadaan naik. Dan pola-pola kenaikan dan pemilihan karenanya pemilihan berkala mengikuti prosedural politik yang melelahkan untuk beberapa anggota politik.

Sedangkan secara spesifik ditentukan oleh faktor :

1. Faktor Biologis

2. Faktor Psikologis

Kedua faktor utama tersebut menjelaskan perputaran posisi elit.

Teori Pertukaran

Teori pertukaran Homans menggambarkan realitas sosial bahwa manusia di tingkat perilaku individual adalah makhluk pencari keuntungan. Teori Homans ini berangkat dari asumsi ekonomi dasar (pilihan rasional), yaitu individu memberi apa dan mendapatkan apa, apakah menguntungkan atau tidak, atau menurut pendapat Bernard teori ini berangkat dari asumsi 'do ut des' saya memberi supaya engkau memberi. Singkatnya teori pertukaran Homans adalah interaksi antar individu yang melakukan pertukaran kepentingan dengan hukum dasar "imbalan dan keuntungan yang didapat oleh individu yang melakukan pertukaran itu".

\section{METODE PENELITIAN}

Lokasi Penelitian

Penelitian ini dilaksanakan di Kabupaten Majene

Tipe Penelitian 
Penulis menggunakan pendekatan kualitatif untuk memahami fenomena sejauh mana persaingan kontestan pada PILKADA di Majene, serta pengaruh elit penentu terhadap pasangan calon dalam perolehan suara.

Teknik Pengumpulan Data

Teknik pengumpulan data yang digunakan dalam penelitian ini adalah teknik wawancara. Penulis melakukan wawancara kepada informan yang berkaitan denga tema penelitian. Teknik pengumpulan data melalui (Arikunto, $2010: 265)$ :

1. Wawancara mendalam, penulis akan menggali informan secara mendalam, penulis akan menggali informasi secara mendalam, terbuka dengan masalah dan fokus penelitian yang diarahkan pada pusat penelitian,

2. Kajian pustaka, bertujuan untuk mengumpulkan data dan informasi ilmiah, berupa terori-teori atau pendekatan yang pernah berkembang dan telah didokumentasikan dalam bentuk, buku, jurnal, dll.

Teknik Analisis Data

Teknik analisis kualitatif digunakan model Miles and Huberman (1994) yang meliputi tiga tahapan. Pertama, reduksi data (data reduction), yakni merangkum, memilih hal-hal pokok, dan memfokuskan pada hal-hal penting dari data yang telah diperoleh dan mencari polanya. Kedua, penyajian data (data display), yakni menampilkan data yang telah direduksi yang sifatnya sudah terorganisasikan dan mudah dipahami. Ketiga, kesimpulan (conclution drawing), yakni akumulasi dari kesimpulan awal yang disertai dengan bukti yang valid, sehingga kesimpulan yang dihasilkan dalam penelitian ini dapat menjawab permasalahan penelitian, yaitu memberikan gambaran tentang rivalitas politik dalam PILKADA Majene tahun 2015.

\section{HASIL DAN PEMBAHASAN}

\section{Persaingan Antara Pasangan Calon Dalam Pemilihan Kepala Daerah di Kabupaten Majene}

\section{Persaingan Antara Fahmi Massiara-Lukman dengan Arifin Nurdin-A. Irfan}

Salah satu faktor penyebab kemenangan Fahmi Massiara-Lukman karena Fahmi Massiara merupakan seorang bangsawan dan memiliki banyak tanah terkhusus di wilayah Kecamatan Banggae Timur. Tanah milik keluarga Fahmi Massiara banyak dipinjam pakai oleh beberapa anggota keluarga di Kecamatan Banggae Timur. Pinjam pakai itu dimanfaatkah oleh keluarga Fahmi Massiara untuk memilihnya dalam PILKADA serentak tahun 2015 di Kecamatan Banggae Timur. Menyikapi manufer yang dilakukan Fahmi Massiara, pasangan Arifin Nurdin yaitu A. Irfan yang juga merupakan bangsawan di Majene, memiliki tanah dipinjam pakai oleh masyarakat melakukan hal yang sama untuk memperoleh suara pemilih.

Fahmi Massiara dan A. Irfan merupakan turunan bangsawan di Majene. Di Majene bangsawan memiliki kedudukan yang terhormat di masyarakat. Bangsawan mendapatkan tempat dan perhatian khusus di masyarakat karena memiliki perbedaan dari masyarakat lainnya. Bangsawan sebagian besar adalah mereka yang memiliki tanah, dan tanah itu diturunkan ke anak cucuk mereka sehingga menguasai sumber-sumber produksi seperti 
menjadi tuan tanah. Tanah milik Fahmi Massiara dan A. Irfan dipinjam pakai oleh masyarakat sehingga hal tersebut dimanfaatkan untuk meraih suara pemilih.

Keuntungan bagi Fahmi Massiara-Lukman karena didukung keluarga Tammalele yang juga memiliki tanah ditempati warga di wilayah Banggae Timur. Jadi terjadi hubungan yang saling menguntungkan antara kandidat yang memiliki tanah dengan pemilih yang menempati tanah. Dimana hubungan tersebut merupakan hubungan timbal balik antara dua orang yang dijalin secara khusus atas dasar saling menguntungkan. Fahmi Massiara dan A. Irfan membiarkan masyarakat menempati tanahnya secara cuma-cuma dengan nilai tukar pemilih yang menempati tanah keluarga Fahmi Massiara, A. Irfan memberikan suaranya pada PILKADA 2015. Begitu juga dengan Tammalele yang mendukung Fahmi Massiara. Warga yang menempati tanah milik keluarga Tammalele, diarahakan untuk memilih pasangan Fahmi Massiara-Lukman. Melalui dukungan Tammalele tersebut memperkuat posisi Fahmi Massiara-Lukman di Kecamatan Banggae Timur.

Kemenangan Fahmi Massiara-Lukman karena kekuatan modal yang dimiliki dalam hal ini modal simbolik yaitu gelar bangsawan, dimana simbol bangsawan selalu menyampaikan suatu kekuasaan atau yang berkuasa, modal finansial yaitu kepemilikan tanah, uang yang memadai dan modal sosial yaitu dukungan tammalele. Bertambahnya sumberdaya karena adanya hubungan yang terjalin antara Fahmi Massiara dengan Tammalele. Tammalele memiliki modal finansial karena merupakan tuan tanah dan memiliki banyak tanah di wilayah Kecamatan Banggae Timur sehingga berpengaruh terhadap perolehan suara Fahmi MassiaraLukman. Sesuai dengan Bourdieu, dominasi modal memperkuat posisi aktor. Selanjutnya Bourdieu menyatakan bahwa tindakan-tindakan manusia dalam interaksi sosialnya tidak lebih dari sebuah pertarungan dan dominasi atas yang lain. Masyarakat tempatnya peleburan sebuah arena berbagai kepentingan kekuasaan, simbol dan kepentingan. Oleh karena itu, modal sangat menentukan.

\section{Persaingan Antara Fahmi Massiara-Lukman dengan Rizal Sirajudin-Mulyadi Bintaha}

Kemenangan Fahmi Massiara-Lukman tidak terlepas dari pemanfaatan relasi sosial yang dibangun sejak menjabat dibirokrasi. Hal tersebut dilihat dari Karir Fahmi Massiara di birokrasi sebagai Camat di Kecamatan Banggae Timur sebelum mencalonkan Wakil Bupati pada tahun 2011.

Fahmi Massiara merupakan pejabat birokrasi sebelum mencalonkan wakil bupati mendampingi Kalma Katta periode 2011-2016. Hal tersebut menjadi modal untuk meraih suara melalui hubungan yang dijalin dengan ASN ketika masih aktif di birokrasi. Kondisi ini sesuai dalam penjelasan Bourdieu, relasi sosial yang terjalin dengan baik merupakan modal sosial. Relasi sosial dengan ASN melalui hubungan kerja yang terbangun dimasa lampau dan masih terjalin dengan baik sehingga dapat dimanfaatkan untuk meraih dukungan suara.

Rizal Sirajuddin-Mulyadi Bintaha melakukan persaingan dengan melakukan hal yang sama yaitu menggalang kekuatan jaringan ASN. Rizal Sirajuddin-Mulyadi Bintaha memulai karirnya di birokrasi. Karirnya dibirokrasi tertinggi saat menduduki jabatan SEKDA di Kabupaten Majene. Selain itu karirnya selama dibirokrasi tidak pernah bermasalah sehingga hal tersebut menjadi modal kuat untuknya pada PILKADA Majene. 
Fahmi Massiara sadar akan dukungan birokrasi terpecah pada PILKADA, Fahmi Massiara melalui Kalma Katta melakukan manuver dengan melakukan mutasi pada ASN yang tidak mendukung incumbent. Penulis melihat ASN yang dimutasi karna mendukung pasangan calon lain merupakan gertakan kepada ASN yang lain untuk tetap mendukung incumbent. Kalma Katta yang pada saat itu masih Bupati di Majene, mengendalikan birokrasi untuk menyatukan kekuatan dan mendukung Fahmi Massiara-Lukman. Meskipun ada beberapa birokrasi yang tidak mendukung, tetapi hal tersebut tidak berpengaruh terhadap perolehan suara Fahmi Massiara-Lukman. Kekuasaan seperti jabatan merupakan modal simbolik. Modal simbolik sebagai jenis sumberdaya yang dapat dioptimalkan dalam meraih dukungan. Simbol itu sendiri memiliki kekuatan untuk mengkonstruksi realitas, yang mampu menggiring orang untuk mempercayai, mengakui dan mengubah pandangan mereka tentang realitas seseorang dan sekelompok orang.

Fahmi Massiara-Lukman dalam menyampaikan visi misi ke masyarakat melibatkan tokoh masyarakat dan tokoh agama. Gambaran dukungan tokoh masyarakat dan tokoh agama dalam perspektif Bourdieu merupakan modal sosial. Hubungan yang terbangun antara Fahmi Massiara-Lukman dengan tokoh masyarakat dan tokoh agama membawa kemenangan terhadap pasangan Fahmi Massiara-Lukman. Melalui dukungan tokoh adat dan tokoh agama membawa pada dukungan kolektif, bukan hanya mewakili individu memberikan dukungan tersebut. Hubungan yang dibangun Fahmi Massiara sejak menjabat sebagai birokrat hingga menjadi Wakil Bupati Majene sehingga memiliki dominasi terhadap kalangan tokoh agama dan tokoh masyarakat. Dominasi tersebut berupa dukungan secara massif dari tokoh agama dan tokoh masyarakat.

\section{Persaingan Antara Arifin Nurdin-A. Irfan dengan Rizal Sirajudin-Mulyadi Bintaha}

Kemenangan pasangan Rizal Sirajuddin-Mulyadi Bintaha di Kecamatan Tammerodo disatu sisi karena jaringan keluarga dari Mulyadi Bintaha yang solid, disisi lain karena keterlibatan Dokter Subaeda mendampingi suaminya yaitu Rizal Sirajuddin. Masyarakat di Kelurahan Tammerodo menaruh kepercayaan terhadap pasangan Rizal Sirajuddin-Mulyadi Bintaha, karena Mulyadi Bintaha merupakan putra asli yang mewakili dari wilayah pegunungan. Selain itu, masyarakat di Kelurahan Tammerodo memiliki keterikatan dengan istri Rizal Sirajuddin yaitu Dokter Subaeda karena kerap membantu masyarakat khususnya dari wilayah pegunungan yang kurang mendapat pelayanan kesehatan karena minimnya fasilitas di wilayah tersebut. Konteks yang disebutkan di atas sesuai dengan perspektif Bourdieu bahwa jaringan dan relasi sosial masuk dalam kategori modal sosial. Dengan adanya jaringan dan relasi sosial sehingga timbul kepercayaan dari masyarakat ke pasangan calon. Masyarakat percaya terhadap Mulyadi Bintaha karena merupakan putra daerah di wilayah tersebut, dan masyarakat percaya terhadap istri Rizal Sirajuddin yaitu dokter Subaeda karena kerap memberi bantuan kesehatan.

Berdasarkan fenomena tersebut perilaku memilih masyarakat Majene memberikan kesan bahwa pilihan rasional masyarakat dalam memilih pemimpinnya cenderung dikesampingkan. Mereka yang pada saat mencoblos, meski memilih secara sadar pilihannya, akan tetapi masih didasarkan pada pertimbangan yang bersifat subjective emotional, memilih karena masih ada ikatan kekeluargaan, kekerabatan, persahabatan.

Pengaruh Elit Penentu Terhadap Pasangan Calon Dalam Perolehan Suara 


\section{Pengaruh Kalma Katta Terhadap Perolehan Suara Fahmi Massiara-Lukman}

Jenjang karir yang baik dari Kalma Katta dimulai dari pegawai dilingkup dinas PU hingga menjadi bupati dua periode di Majene disebabkan seorang Kalma Katta memiliki kapabilitas diakibatkan tingkat intelektuallitasnya yang memadai. Oleh sebab itu Kalma Katta mampu menjadi problem solver dari setiap masalah dalam proses pemerintahan di Majene sewaktu ia menjabat sebagai bupati. Kalma Katta sangat berpengaruh dalam mendukung pasangan Fahmi Massiara dan Lukman disebabkan Kalma Katta mempunyai posisi, dalam pandangan masyarakat pemilih kesuksesan saat menjabat sebagai Bupati Majene dua periode memberikan kesan kepada pemilih dan juga kepada Fahmi Massiara, dimana Fahmi Massiara yang berpasangan dengan Kalma Katta dianggap representasi kesuksesan Kalma Katta. Representase kesuksesan tersebut merupakan bentuk reputasi besar dan elit itu sendiri. Dalam konteks penelitian ini, elit penentu yang dimaksud adalah orang yang posisinya sebagai penentu kemenangan kandidat.

Dalam konteks penelitian ini, elit penentu yang dimaksud adalah orang yang posisinya sebagai penentu kemenangan kandidat. Dalam perspektif Suzanne Keller, Kalma Katta sebagai elit penentu dalam kontestasi politik di Majene memiliki kelebihan dibandingkan elit lainnya karena elit tersebut memiliki sumberdaya sebagai kekuatan. Kalma Katta memiliki sumberdaya berupa jaringan yang dibangun sampai ke grassroot selama menjabat sebagai Bupati di Majene. Selain itu kekuasaan Kalma Katta sebagai ketua DPD II partai GOLKAR di Majene menjadi modal politik, sehingga Kalma Katta memiliki kekuasaan untuk mengusung pasangan Fahmi Massiara-Lukman pada PILKADA di Majene.

Dalam kategori spesialisasi yang disebutkan oleh Keller menempatkan bahwa seseorang dapat menjadi elit penentu. Dalam kondisi seperti ini Kalma Katta menjadi elit penentu karena Karir Kalma Katta yang bermula dari birokrasi hingga akhirnya menjadi wakil bupati. Jenjang karir yang terus meningkat dan berada diposisi sebagai Bupati dan Ketua DPD II Partai GOLKAR. Melalui karir tersebut Kalma Katta membangun interaksi sosialnya dengan masyarakat. Melalui berbagai aktifitas Kalma Katta di Kabupaten Majene, sehingga terbangun kepercayaan masyarakat terhadap Kalma Katta. Sehingga masyarakat di Kabupaten Majene memberikan pilihannya ke pasangan Fahmi Massiara-Lukman karena Kalma Katta juga mendukung pasangan calon tersebut.

Kalma Katta mendukung pasangan Fahmi Massiara-Lukman karena memiliki kepentingan, dimana Kalma Katta mengikuti PILGUB Sulawesi Barat sebagai wakil dari Suhardi Duka. Selain itu Kalma Katta sebagai Ketua DPD II partai GOLKAR di Majene yang mengusung pasangan Fahmi Massiara-Lukman tentu berusaha memenangkan pasangan Fahmi Massiara-Lukman. Dengan kemenangan Fahmi Massiara-Lukman, maka pada PILGUB Sulawesi Barat Fahmi Massiara terlibat dalam tim pemenangan Suhardi DukaKalma Katta.

Pengaruh Kalma Katta telah membawa Fahmi Massiara-Lukman memperoleh kemenangan pada PILKADA Majene. Maka pada PILGUB Sulawesi Barat Fahmi MassiaraLukman mendukung sepenuhnya pasangan Suhardi Duka-Kalma Katta yang sebelumnya telah membangun komitmen politik untuk mendukung Suhardi Duka-Kalma Katta pada PILGUB. Bentuk dukungan Fahmi Massiara dilihat pada keterlibatan Fahmi Massiara secara langsung mensosialisasikan pasangan Suhardi Duka-Kalma Katta di Majene. 
Komitmen politik yang sudah terbangun dari awal antara Kalma Katta dan pasangan Fahmi Massiara-Lukman, sehingga Fahmi Massiara memberikan dukungan sebagai penanggung jawab tim pemenangan Suhardi Duka-Kalma Katta di Kabupaten Majene dan pada akhirnya pasangan Suhardi Duka-Kalma Katta memperoleh kemenangan di Majene pada PILGUB Sulawesi Barat. Hal tersebut digambarkan pada perolehan suara sah di Kabupaten Majene.

Tabel

Perolehan Suara Sah Kabupaten Majene

\begin{tabular}{|c|c|c|}
\hline NO & $\begin{array}{c}\text { Pasangan } \\
\text { Calon }\end{array}$ & Kelurahan Adolang \\
\hline 1 & $\begin{array}{c}\text { H. Suhardi Duka- } \\
\text { Kalma Katta }\end{array}$ & 42.854 \\
\hline 2 & $\begin{array}{c}\text { Mayjen Purn Salim S } \\
\text { Mengga-Hasanuddin Mas'ud }\end{array}$ & 21.375 \\
\hline 3 & $\begin{array}{c}\text { Ali Baal Masdar-Enny } \\
\text { Angraeni Anwar }\end{array}$ \\
\hline
\end{tabular}

Sumber Data : KPU Kab. Majene 2017

Diolah Kembali Oleh Penulis 2017

Gambaran terhadap fakta bahwa apa yang disebutkan teori T.B Bottomore menunjukan tentang hubungan dukung mendukung dan loyalitas tergambarkan pada relasi antara Kalma Katta dan Fahmi Massiara. Loyalitas timbul disebabkan ada kepentingan diantara keduanya. Sehingga kedua elite ini (Kalma Katta dan Fahmi Massiara) saling memanfaatkan untuk mencapai kepentingannya masing-masing. Kepentingan Kalma Katta terkait pencalonan dirinya dalam PILGUB Sulawesi Barat 2017 untuk menarik dukungan suara dan menjaga eksistensinya di Majene, maka Fahmi Massiara yang pernah menjadi wakilnya didukung untuk menjadi calon bupati di Majene tahun 2015.

Mengenai loyalitas sehingga terjadi pertukaran dukungan dalam pandangan Homans, bahwa individu dalam hubungan sosial melakukan tawar menawar kepentingan sesuai kebutuhan individu. Fahmi Massiara-Lukman melakukan tawar menawar kepentingan karena Fahmi Massiara mengikuti kontestasi PILKADA, begitu juga dengan Kalma Katta yang mengikuti kontestasi PILGUB Sulawesi Barat. Kalma Katta memberikan dukungan dengan imbalan Fahmi Massiara-Lukman mendukung pada perolehan suara di Majene. Fahmi Massiara-Lukman akan menukar dukungannya disebabkan adanya orientasi pribadi yang diinginkan khususnya imbalan bentuk dukungan yang didapatkan dari Kalma Katta. Begitu juga dengan Kalma Katta memiliki orientasi pribadi sehingga mendukung pencalonan Fahmi Massiara-Lukman. Orientasi pribadi sangat erat kaitannya dengan nilai yang mereka harapkan dari pasangan calon terkait.

\section{Pengaruh Ali Baal Masdar Terhadap Perolehan Suara Arifin Nurdin-A. Irfan}

Klan Masdar memiliki basis solid yang kuat. Hingga keuanggulannya mendominasi di Kabupaten Polewali Mandar yang berpenduduk terbesar di Sulawesi Barat, terbukti tiga kali berturut-turut klan Masdar mampu bertahan dari kontestasi PILKADA. Faktor penyebab menguatnya klan Masdar karena adanya akumulasi modal yang dimiliki. 
Selain itu, Klan Masdar familiar di Sulawesi Barat karena berasal dari keluarga Maraqdia yaitu Maraqdia Tapango. Dari latar belakang keluarga yang sudah terkenal sehingga nama Ali Baal Masdar populer di Sulawesi Barat begitu juga di Kabupaten Majene. Apalagi Ali Baal Masdar mempersunting A. Ruskati yang merupakan anak dari Maraqdia di Majene. Nama Masdar ini selain menjadi alat penarik dukungan terhadap masyarakat pemilih, juga menjadi modal politik terkait menentukan pemenangan politik.

Dalam kategori biologis yang disebutkan oleh Keller menempatkan bahwa seseorang dapat menjadi elit penentu. Ali Baal Masdar dikatakan sebagai elit penentu karena faktor biologis terkait dengan turun temurun. Ali Baal Masdar memiliki posisi strategis dan menjadi elit dikelompok masyarakat pemilih di Sulawesi Barat dikarenakan Ali Baal Masdar anak dari Masdar, yang essensinya Masdar juga merupakan Raja dari Kerajaan Tapango. Pengaruh nama Masdar ini dimanfaatkan oleh Ali Baal Masdar menjadi simbolistik politik untuk menarik dukungan karena masyarakat Sulawesi Barat masih terikat filosifis kerjaan tersebut. Warisan kerajaan masa lampau di Mandar yang masih berpengaruh hingga sekarang adalah pengaruh kaum bangsawan di bidang sosial politik di daerah itu. Bangsawan Mandar dengan gelar Daeng dan Puang menduduki posisi terhormat dalam masyarakat.

Pada faktor biologis, Ali Baal Masdar dari turunan bangsawan berbeda dengan masyarakat lainnya sehingga ditempatkan dalam golongan atas orang terpandang. Pada struktur masyarakat di daerah Mandar, Ali Baal Masdar termasuk ke dalam golongan bangsawan raja karena masih turunan dari Raja Tapango. Dari keunggulan tersebut sehingga Ali Baal Masdar ditempatkan dalam lapisan elit. Dalam konteks tersebut sejalan dengan pandangan J.W schoorl seseorang ditempatkan dalam tipe elit dinastik. Ali Baal Masdar temasuk dalam kategori elit dinastik karena berasal dari lingkungan aristokrasi atau keturunan bangsawan di Mandar.

Nama Masdar ini selain menjadi alat penarik dukungan terhadap masyarakat pemilih, juga menjadi modal politik terkait menentukan pemenangan politik. Pemilihan Kepala Daerah tahun 2015 Ali Baal Masdar mendukung Arifin Nurdin-A. Irfan. Dukungan yang diberikan Ali Baal Masdar tersebut karena A. Irfan dan Ali Baal Masdar memiliki hubungan keluarga yaitu masih saudara sepupu. Andi Irfan merupakan anak dari Hj. Andi Hebawaty Pasilong dan Andi Sulaiman Balimalipu. Selain itu, A. Ruskati istri dari Ali Baal Masdar merupakan ketua DPD GERINDRA Sulawesi Barat, secara kelembagaan mengusung pasangan Arifin Nurdin-A. Irfan pada PILKADA Majene, dimana A. Irfan merupakan ketua partai GERINDRA di Kabupaten Majene.

Ali Baal Masdar memiliki kepentingan atas dukungannya ke pasangan Arifin NurdinA. Irfan yaitu untuk memuluskan langkahnya pada PILGUB Sulawesi Barat. Jika pasangan Arifin Nurdin-A. Irfan memperoleh kemenangan pada PILKADA tentu akan memudahkan Ali Baal Masdar pada perolehan suara PILGUB Sulawesi Barat. Meskipun pasangan Arifin Nurdin-A. Irfan kalah dalam kontestasi PILKADA, pada moment PILGUB Sulawasi Barat pasangan Arifin Nurdin-A. Irfan, memfasilitasi dalam artian membantu pasangan Ali Baal Masdar-Anggaraeny Anwar Saleh dalam perolehan suara di Majene.

Fenomena interaksi sosial tersebut menggambarkan prosisi nilai yang dikemukakan oleh Homans bahwa semakin tinggi nilai tindakan seseorang, maka semakin besar kemungkinan orang itu melakukan hal yang sama. Tindakan Ali Baal Masdar pada PILKADA Majene yaitu memberikan dukungan dengan ikut melibatkan diri pada kampanye, 
sosialisasi visi misi serta memberikan bantuan finansial kepada pasangan Arifin Nurdin-A. Irfan. Melalui gambaran fenomena tersebut dalam perspektif Homans tindakan Ali Baal Masdar bernilai tinggi karena Ali Baal Masdar adalah bangsawan yang memiliki pengaruh melalui hubungan sosial yaitu ikatan kekerabatan. Dari tindakan Ali Baal Masdar tersebut, Arifin Nurdin-A. Irfan melakukan hal yang sama yaitu dengan ikut terlibat pada struktur pemenangan Ali Baal Masdar di Majene, sehingga Ali Baal Masdar memperoleh urutan kedua dengan perolehan suara sah 26.651 suara pada perolehan suara PILGUB Sulawesi Barat.

\section{Pengaruh Muhyina Muin Terhadap Perolehan Suara Rizal Sirajuddin Mulyadi Bintaha}

Muhyina Muin popular di Majene disatu sisi karena anak dari dari Prof. Muin Liwa dan $\mathrm{Hj}$. Najamiah. Kedua orang tua Muhyina Muin berasal dari Suku Mandar. Prof Muin Liwa adalah salah satu guru besar di Fakultas Peternakan UNHAS dan memiliki peran dalam pendirian UNSULBAR yang awalnya perguruan tinggi swasta 2008 hingga dialih status menjadi Perguruan Tinggi Negeri, dikukuhkan menjadi Rektor pertama di UNSULBAR, dan Hj. Najamiah adalah pengusaha yang terkenal dan sukses di Makassar. Disisi lain kepopuleran Muhyina Muin karena kepemilikan finansial yang memadai. Sejak saat itu Rizal Sirajuddin melalui $\mathrm{Hj}$. Najamiah membangun relasi politik dengan Muhyina Muin, dimana Rizal Sirajuddin sebagai calon kandidat pada PILKADA 2015.

Kekuatan Finansial yang dimiliki Muhyina Muin sehingga mampu menarik beberapa simpati masyarakat di Kabupaten Majene. Stigma yang terbangun bahwa Muhyina Muin adalah perempuan yang dermawan kerap memberikan bantuan kepada masyarakat yang kurang mampu. Terkhusus masyarakat di Kelurahan Tandeallo yang menerima bantuan dari Muhyina Muin. Sehingga pada PILKADA Majene, masyarakat di Kelurahan Tandeallo memilih pasangan Rizal Sirajuddin-Mulyadi Bintaha karena pasangan calon tersebut mendapat dukungan dari Muhyina Muin.

Muhyina Muin tidak secara maksimal memberikan dukunannya kepada pasangan Rizal Sirajuddin Mulyadi Bintaha karena Muhyina Muin merupakan kader partai GOLKAR, Rizal Sirajuddin-Mulyadi Bintaha diusung partai PAN pada PILKADA Majene. Sehingga pihak Muhyina Muin tidak telibat dalam proses sosialisasi visi misi pasangan Rizal Sirajuddin-Mulyadi Bintaha. Muhyina Muin hanya hadir satu kali pada kampanye akbar di lapangan Sendana, tetapi tidak secara terang-terangan mendeklarasikan dukungannya ke Rizal Sirajuddin-Mulyadi Bintaha. Muhyina Muin hanya memberikan uang ke masyarakat pada kampanye tersebut.

Gambaran terhadap fakta bahwa apa yang disebutkan Keller menunjukan secara spesifik Muhyina Muin dapat dikatakan sebagai elit penentu karena Muhyina Muin memiliki sumberdaya yaitu finansial yang merupakan turunan dari orang tuanya. Dengan Finansial tersebut sehingga Muhyina Muin memiliki keunggulan dan keistimewan sehingga mampu membangun kerjasama dengan Rizal Sirajuddin-Mulyadi Bintaha. Dalam hal keunggulan dari sumberdaya finansial dalam perspektif J.W Schoorl Muhyina Muin merupakan elit kelas menenangah karena Muhyina Muin memiliki finansial yang kuat.

\section{KESIMPULAN DAN SARAN}


Berdasarkan hasil penelitian dan pembahasan, maka ada dua hal yang dapat disimpulkan oleh penulis yaitu, Persaingan ketiga pasangan calon pada PILKADA Majene dilihat pada kekuatan modal yang digunakan untuk bersaing. Kekuatan masing-masing pasangan calon terjabarkan dalam pemilikan modal-modal. Kekuatan Fahmi MassiaraLukman sehingga memenangkan kontestastasi PILKADA yaitu pada kemampuan Fahmi Massiar-Lukman mengakumulasi modalitas dalam hal ini modal finansial dilihat pada kepemilikan tanah dan uang, modal sosial terjabarkan dari dukungan Kalma Katta, keterlibatan tokoh agama dan tokoh masyarakat dalam menyampaikan visi misi. Fahmi Massiara merupakan bangsawan di Majene dan wakil dari Kalma Katta merupakan modal simbolik. Kekuatan modal Pasangan Arifin Nurdin-A. Irfan yaitu modal finansial terjabarkan dalam kepemilikan akan tanah dan modal kultural berupa popularitas jenjang pendidikan memadai. Kekuatan Pasangan Rizal Sirajudidin-Mulyadi Bintaha dalam bersaing yaitu pada modal finansial dan modal simbolik terjabarkan pada background Rizal Sirajuddin-Mulyadi Bintaha yang merupakan mantan pejabat birokrasi.

Ketiga pasang calon mendapat dukungan dari elit penentu yang berpengaruh dalam perolehan suara. Fahmi Massiara-Lukman didukung Kalma Katta, Arifin Nurdin-A. Irfan didukung Ali Baal Masdar dan Rizal Sirajuddin didukung oleh Muhyina Muiin. Pengaruh Kalma dilihat pada posisinya yang merupakan bupati dua periode di Majene dan merupakan Ketua DPD Partai GOLKAR. Pengaruh Ali Baal Masdar dilihat pada simbol bangsawan yang memiliki jaringan keluarga solid dan kepemilikan modal finansial yang memadai. Pengaruh Muhyina Muin dilihat pada kepemilikan modal finansial. Sehingga ketiga elit penentu tersebut sebagai faktor penentu pada perolehan suara pasangan calon.

Adapun saran penelitian adalah seyogyanya calon kepala daerah lebih memfokuskan perhatiannya kepada kebijakan dan pogram yang menyentuh kepentingan semua segmen untuk kesejahteraan masyarakat secara keseluruhan dan seyogyanya pertukaran kepentingan antara calon Bupati dan elit penentu merupakan pertukaran kepentingan rasional yang tidak melanggar peraturan perundang-undangan.

\section{Daftar Pustaka}

Budiarjo, Miriam.1998. Dasar-Dasar Ilmu Politik. Jakarta: PT. Gramedia Pustaka Utama

Bottomore. 1966. Elit dan Masyarakat. Jakarta : Akbar Tandjung Institute

Duverger,Maurice. 2005. Sosiologi Politik. Jakarta : PT. Raja Grafindo Persada

Dr.Nasikun. 1995 Sistem Sosial Indonesia. Jakarta : PT. Raja Grafindo Persada

Dr. Muhadam Labolo.2015. Dinamika Politik dan Pemerintahan Lokal. Ghalia Indonesia

Elly M. Setiadi, Usman Kolip. 2011. Pengantar Sosiologi : Pemahaman Fakta dan Gejala Permasalahan Sosial : Teori, Aplikasi dan Pemecahannya. Jakarta : Kencana

Firmanzah. 2007. Marketing Politik, Jakarta : Obor 
2010. Persaingan, Legitimasi Kekuasaan, dan Marketing Politik, Jakarta : Yayasan Pustaka Obor Indonesia

Keller, Suzanne. 1963. Penguasa dan Kelompok Elit. Peranan Elit Penentu dalam Masyarakat Modern. Jakarta : CV, Rajawali

Lexy. J. Moleong. 2000. Metodologi Penelitian Kualitatif. Bandung: PT. Remaja Rosdakarya

MB. Zubakhrum Tjenreng. 2016. Pilkada Serentak Penguatan Demokrasi di Indonesia. Pustaka Kemang

Marsh David, Stoker Gerry. 2002. Teori dan Metode dalam Ilmu Politik. Bandung. Nusa Media

Miles, Matthew B. and A. Michael Huberman. 1994. Qualitative Analysis Data. London: Sage

Ramlan Surbakti . 1992. Memahami Ilmu Politik, Jakarta : PT Grasindo.

Rudi Salam Sinaga. 2013 Pengantar Ilmu Politik : Kerangka Berpikir dalam Dimensi Arts, Praxis dan Policy Yogyakarta : Graha Ilmu,

Raho, Bernard. 2007, Teori Sosiologi Modern, Jakarta: Prestasi Pustaka.

Ritzer, George and Douglas J. Goodman (ter) Aliman dan Triwibowo Budi Santoso, 2008. Teori Sosiologi Modern, Jakarta: Kencana Prenada Media Group.

Ritzer, George. 2011. Teori Sosiologi dari Sosiologi Klasik sampai Perkembangan Terakhir Postmodern. Edisi ke-8. Diterjemahkan dari: Sociological Theory $8^{\text {th }}$ edition by George Ritzer. Yogyakarta: Pustaka Pelajar.

Schoorl. 1982. Elite Dalam Modernisasi. Gramedia 